\title{
Sombras literárias: a fotonovela e a produção cultural
}

\section{Literary shadows: the strip cartoon and cultural production}

André Luiz Joanilho*

Mariângela Peccioli Galli Joanilho **

\section{Resumo}

As fotonovelas tiveram um mercado cativo por mais de 25 anos no Brasil, e milhões de leitores consumiram ansiosamente histórias publicadas em revistas com larga circulação nacional. No entanto, foram ignoradas quase que completamente por críticos e estudiosos e consideradas um subgênero da literatura. Seus leitores foram marcados, entre outros aspectos, como de baixa formação cultural e possuidores de parcos rendimentos. Entretanto, seria possível para o historiador não reconhecer a leitura de fotonovelas como uma manifestação de práticas sociais? Poderia a cultura de massa ter criado um conjunto enorme de leitores sem face e sem gosto? Estas questões nos permitem pensar as representações sociais femininas no Brasil e as práticas de leitura das décadas de 1950 e 1960.

Palavras-chave: história cultural; linguagem; leitura.

\section{Abstract}

Strip cartoons had a captive market for more than twenty years in Brazil and millions of readers eagerly consumed stories published in magazines with national circulation. Nevertheless this type of vehicle was almost completely ignored by scholars and considered a subgenre of literature, and its reading public considered as of low cultural capacity and low income level. However, is it possible for the historian not to recognize cartoon strips as a social practice? Could mass culture have created an enormous number of readers without face and taste? These questions bring to the fore the feminist social movements in Brazil and the reading practices of the fifties and sixties.

Keywords: cultural history; language; reading.

\footnotetext{
* Professor Associado - Universidade Estadual de Londrina (UEL). alj@uel.br.

** Professora Adjunta-B - Depto. de História, Universidade Estadual de Londrina (UEL). Rodovia Celso Garcia Cid, s/n. Caixa Postal 791. 86038-440 Londrina - PR — Brasil. deptlet@ uel.br.
} 
Um fantasma assombra o mundo da boa literatura: a má literatura, especialmente aquela das revistas femininas populares. Qual crítico não torce o nariz diante de livros como Júlia, Sabrina ou Bianca, publicações da editora Nova Cultural, que trazem os estigmas de uma literatura negada pelo bom gosto definido nos cânones? Mais ainda, a derrisão que portam é tão grande que nem sequer merecem ser citados. São sombras literárias que se projetam na escuridão, uma não existência.

No entanto estão aí. São vendidos aos milhares a cada edição e revendidos por sebos no país todo, tomados de empréstimo, lidos nas salas de espera de consultórios. Logo, há um grande mercado editorial que não é levado em consideração pelas instituições que determinam o que é uma boa obra literária e o que não é. São publicações completamente ignoradas mesmo atingindo um público tão extenso. Ainda assim, são lidas, muitas vezes envergonhadamente, a despeito da crítica ácida que recebem de algum estudioso que se digna a gastar poucas palavras sobre o assunto.

É comum pensar-se que a boa literatura é boa por méritos intrínsecos, ou seja, porta em si os sinais que a qualificam como boa. Quando alguém escreve um romance, conto, poema, espera-se que possua qualidades inerentes a um bom artista. Que domine a técnica de escrita, que saiba compor a trama, que tenha sob o seu domínio as palavras e que as use sabiamente. Como o autor alcança tais qualidades ainda é fruto de discussão entre magia e ciência, pois se é um dom ou coincidência genética não é algo definido.

Espera-se, também, que a obra contenha em si o necessário para classificá-la como literária e, assim, é por vezes associada à figura do autor. Muitos estudiosos gostam de vincular uma possível biografia à obra. Por exemplo, Machado de Assis e Memórias póstumas de Brás Cubas. Vejamos:

quando o romancista assumiu, naquele livro capital, o foco narrativo, na verdade passou ao defunto autor Machado-Brás Cubas delegação para exibir, com o despejo dos que já nada mais temem, as peças de cinismo e indiferença com que via montada a história dos homens. ${ }^{1}$

Essa imbricação do autor com o texto passa a um segundo momento, quando se autonomiza, ou melhor, é autonomizada:

foi nesse livro surpreendente que Machado descobriu, antes de Pirandello e de Proust, que o estatuto da personagem na ficção não depende, para sustentar-se, da sua fixidez psicológica, nem de sua conversão em tipo; e que o registro das sensações 
e dos estados de consciência mais díspares veicula de modo exemplar algo que está aquém da persona: o contínuo da psique humana. (Bosi, 1985, p.200)

Assim, a obra normalmente é analisada de duas formas: sincronicamente, quando é comparada a outras do mesmo período, podendo fazer parte de uma 'escola' literária; e também diacronicamente, quando é ordenada na sucessão de escolas literárias, compondo o quadro de uma possível literatura nacional que, por sua vez, entra num jogo de comparações com outros quadros nacionais. Definem-se diferenças e similitudes entre nações e, desta forma, surge uma literatura mundial que teria as mesmas propriedades das eras geológicas que se sucedem temporalmente. Pode-se dizer que a diacronia em escala mundial permite uma espécie de darwinismo literário: escolas literárias evoluem da mesma forma que primatas.

Acompanhando estes procedimentos na análise e crítica, é possível observar que todo bem cultural dirigido às massas passa por uma não-análise, quer dizer, há uma derrisão em torno desses artefatos que não merecem a tinta do crítico de arte. Quando este se dispõe a fazer algum estudo sobre esse tipo de bem, é para desqualificá-lo, caso das revistas femininas populares que recebem freqüentemente a pecha de subliteratura ou, simplesmente, não literatura, não merecendo sequer uma análise dos seus princípios narrativos, estéticos e estilísticos. Mesmo porque não possui internamente as qualidades necessárias para que possa alcançar o status de obra literária, enquanto tem todos os elementos externos para qualificá-la como produto da cultura de massa, tais como produção em larga escala, histórias repetitivas e sem qualidade literária, personagens sem profundidade psicológica, happy-ends, conflitos sociais reduzidos a problemas individuais etc.

Dentro deste quadro, a fotonovela é a prima pobre dos subgêneros literários. São citadas apenas ocasionalmente, muitas vezes funcionando como contra-exemplo, uma não literatura, ou meramente um produto da cultura de massa, que não tem outro objetivo além de caçar níqueis nas carteiras de consumidores desavisados ou não suficientemente educados para evitar produto tão enganoso. Ainda tem um lado mais perverso: funcionar como anestésico da consciência popular.

A definição de 'telenovela' no E-dicionário de termos literários, editado e organizado por Carlos Ceia, ${ }^{2}$ é elucidativa:

Considerada um subgénero da literatura, a fotonovela é uma narrativa mais ou menos longa que conjuga texto verbal e fotografia. A história é narrada numa 
sequência de quadradinhos (como a banda desenhada) e a cada quadradinho corresponde uma fotografia acompanhada por uma mensagem textual.

Mais tarde a fotonovela torna-se independente do cinema e caracteriza-se pelas suas intrigas sentimentais (a heroína é quase sempre uma rapariga de origem modesta que sonha com um amor cheio de obstáculos e dificuldades mas no final consegue o seu objectivo), as personagens não demonstram um grande desenvolvimento psicológico e são sempre estereotipadas (os bons são sempre bons e os maus arrependem-se no final ou sofrem as consequências), predomina o imaginário exótico, e, mais tarde o 'suspense' e o sexo, os temas variam entre problemas afectivos, sociais, a procura de sucesso numa carreira, a justiça na sociedade, a ascensão social, a marginalidade, etc.

$\mathrm{O}$ público da fotonovela é um público majoritariamente feminino e culturalmente pouco exigente, com pouca formação e com um baixo poder económico. As revistas de fotonovela têm como finalidade a transmissão dos princípios éticos, morais e sociais concordantes com o sistema de valores da ideologia dominante através da integração da mulher na sociedade urbana.

Não há dúvida quanto ao caráter da fotonovela. Ela é um subproduto da literatura chamada de modo eufemístico de subgênero. Esse artefato cultural é claramente desqualificado como incapaz de promover algum gosto no público leitor que, por sua vez, também é desqualificado. A baixa formação escolar e os parcos rendimentos de quem a consome denotam que a fotonovela é voltada para aqueles que têm uma capacidade de discernimento bem prejudicada. Pelo menos é o que se pode inferir, tendo em vista a transmissão de valores conservadores e de hegemonia ideológica aos quais os leitores estão expostos.

Enfim, é um produto de massa, com grande público leitor, e é incapaz de apresentar algo que literariamente possa ser considerado digno de uma avaliação. Não que haja erro nas avaliações ou que se devote desprezo a esse tipo de folhetim por má vontade. Realmente as histórias são açucaradas e quase monotemáticas, porém, o lugar reservado para elas no ranking das produções literárias é o das obras indignas. Elas existem, mas ninguém deve lê-las.

Quais seriam os motivos de tão solene derrisão? Não são revistas que trazem histórias com uma narrativa, personagens, trama e demais quesitos que um romance deve ter? Por que são histórias que não têm validade literária? Por que foram relegadas a um mundo de sombras, sem luz? Afinal, o que é uma boa e uma má literatura?

Como obra, a fotonovela seria o eufemismo do pastiche. Pastiche do 
folhetim, do cinema, dos quadrinhos, da literatura, da fotografia, enfim, reúne em si o que há de mais kitsch na cultura ocidental e "kitsch é o que surge consumido; o que chega às massas ou ao público médio porque já está consumido; e que se consome (e, portanto, se depaupera) porque o uso a que foi submetido por um grande número de consumidores lhes apressou e aprofundou o desgaste", ${ }^{3}$ ou ainda: "a fotonovela desde o início era sub-kitsch, utilizando sem qualquer vergonha todos os recursos do déjà vu para um público totalmente popular". ${ }^{4}$

A fotonovela é a contraprova da obra de arte. Definida pelo negativo, ela nos aponta qual literatura não deve ser consumida, quer dizer, ela própria. Uma verdadeira anti-arte. É uma maneira perversa e insidiosa de reproduzir valores culturais conservadores e individualistas: "enfim, a fotonovela abraçou fortemente o estereótipo em todos os níveis. Abraço forte, na forma e no conteúdo. Amor dominador deu no que deu: pouca liberdade de criação, personagens marionetes, maniqueísmo, estrutura fechada, ideologia conservadora". ${ }^{5}$

Não há escapatória, esse artefato é realmente um produto da cultura de massa, logo alienante. Não possui em si nenhuma característica de uma boa literatura, mesmo quando utiliza romances consagrados como roteiro (Conde de Monte Cristo, Ana Karênina, O morro dos ventos uivantes etc.), pois os pasteuriza empobrecendo-os: "a fotonovela não cria inteiramente sua atmosfera, mas está seguidamente realizando 'pastiches"”. ${ }^{6}$ Isto ocorre porque essa literatura é uma forma de "popularização de mensagens permissíveis e manipuladas que estão associadas ao poder" (Habert, 1984, p.18).

Não se trata aqui de opor opiniões e estabelecer um novo artefato cultural, colocando-o como superior, buscando inverter as críticas sobre a fotonovela. Trata-se antes de compreender os mecanismos pelos quais se estabelece algo como culturalmente válido ou não.

Dessa forma, deve-se, em primeiro lugar, compreender que "o sistema de produção e circulação de bens simbólicos define-se como o sistema de relações objetivas entre diferentes instâncias definidas pelas funções que cumprem na divisão do trabalho de produção, de reprodução e de difusão de bens simbólicos". ${ }^{7}$ Nesse sentido, entram em cena diversas instâncias que procuram definir o que é arte qualificando-a como superior ou inferior, erudita ou popular, alta ou baixa e assim por diante. Nesse aspecto, determinados bens simbólicos são tachados como superiores enquanto outros podem ser objetos de consumo em massa. 
A definição da superioridade de um artefato nada tem a ver com suas qualidades intrínsecas, porque o

campo da produção erudita tende a produzir ele mesmo suas normas de produção e critérios de avaliação de seus produtos, e obedece à lei fundamental da concorrência pelo reconhecimento propriamente cultural concedido pelo grupo de pares que são, ao mesmo tempo, clientes privilegiados e concorrentes. (Bourdieu, 1987, p.105)

Isto é, podemos chamar a definição do que é um objeto válido culturalmente como 'superior' por um novo esoterismo. Os códigos de acesso para objetos eruditos são restritos e restritivos e somente após longo aprendizado podem ser compreendidos, o que garante a sua reprodução simples e ao mesmo tempo serve para a manutenção desse mercado restrito.

Tais procedimentos podem ser observados quando:

o reconhecimento implícito da legitimidade cultural transparece, sobretudo, através de dois tipos de conduta aparentemente opostas: a distância respeitosa dos consumos mais legítimos (um bom testemunho nos é dado pela atitude dos visitantes das classes populares nos museus) e a negação envergonhada das práticas heterodoxas. (Bourdieu, 1987, p.132)

\section{Dessa forma:}

fundamentalmente heterônoma, a cultura média é objetivamente definida pelo fato de estar condenada a definir-se em relação à cultura legítima, tanto no âmbito da produção como no da recepção. As investigações originais que podem suceder no sistema da indústria cultural estão sempre limitadas pelos bloqueios de comunicação que correm o risco de provocar mediante o uso de códigos inacessíveis ao 'grande público’. (Bourdieu, 1987, p.143)

A determinação do que é ou não é válido funciona como campo de legitimação de objetos culturais e, conseqüentemente, de distinção de seus consumidores como 'superiores' àqueles que não conhecem os códigos de validação. Aliás, estes são efêmeros, pois estabelecidos temporalmente. Conforme as posições de força dos vários agentes, são impostos como 'verdadeiros' e legítimos.

Portanto, os códigos estão sempre em disputa. Não como fórmulas genéricas, verdadeiras e atemporais, em que cada época conheceria uma parcela, 
mas criados a cada momento específico por diferentes grupos ou classes. Logo, o fracasso de um artefato cultural e a ascensão de um novo tem como pano de fundo essa luta em torno de quem pode estabelecer os códigos.

O estabelecimento dessas formas de avaliação artística e estética, como também a imposição de formas de comportamento dos consumidores de artefatos culturais considerados de boa qualidade, tornou-se meio para demarcar modos de distinção social, pois a distância econômica por ser apagada pela 'democratização' do consumo de bens materiais. Por isso, a definição e a imposição da cultura superior como legítima se estabelecem em oposição à chamada cultura popular, fazendo que estes dois campos apareçam como dados e naturalmente estabelecidos. No entanto, cabe ressaltar que essa separação é relativamente recente e não natural. ${ }^{8}$

A apropriação de determinados artefatos culturais por parte da elite não tem como fundo a sua qualidade intrínseca, mas a possibilidade de apresentálos como exclusivos de classe. Academias, universidades, críticos e estudiosos corroboram a criação desse mercado exclusivo de bens simbólicos. A determinação da alta cultura e da baixa cultura é resultado da luta interna das camadas superiores da sociedade para estipularem o que lhes caberia como bens simbólicos ou não. Poucas vezes o critério foi exclusivamente o do valor, mas ele pode completar a distinção entre diferentes bens. Por exemplo, o teatro no Antigo Regime era feito praticamente para o público em geral. A sua apropriação, no século XIX, pela elite, o tornou dispendioso e exclusivo. Nesta mesma linha, os conteúdos dos bens ganham complexidade e valor conforme são dirigidos a consumos cada vez mais restritos.

Formam-se círculos de legitimação, exclusão e distinção no campo dos bens simbólicos, dos quais o que é compreendido como campo da cultura popular será o que não terá alguma autonomia e, portanto, capacidade de ditar suas próprias normas, pois a sua legitimação passa pelo crivo dos produtores culturais. A sua legitimação depende, portanto, de fórmulas "esotéricas" produzidas por alguns experts "altamente capacitados” (Bourdieu, 1987, p.130).

Porém, devemos atentar para os conceitos de cultura popular e cultura erudita. Se até há pouco tempo não havia distinção entre os dois campos, o estabelecimento da diferença se fez à custa de outra compreensão a respeito de cultura, que a tomaria como uma prática social e não como campo excludente. No entanto, encontra-se justamente a naturalização da distinção entre dois campos, um alto e outro baixo, um erudito e outro popular, um superior 
e outro inferior. Compreende-se a cultura a partir de pares/oposições como se fossem constitutivos dela própria.

Podemos, em primeiro lugar, opor a essa compreensão o conceito de cultura apresentado por Roger Chartier, no qual vemos que a constituição dos campos culturais obedeceu a regras externas a eles próprios. E, em segundo lugar, temos a definição de consumo de Michel de Certeau. A partir desses dois pensadores, podemos verificar, de início, que a lógica da análise obedece à lógica do campo científico e não à das práticas culturais, impondo pares/ oposições.

Neste aspecto, o 'popular' sofre uma análise externa, coletiva e quantitativa. Externa porque o estudioso da cultura popular o analisa a partir do ponto de vista da erudição, do seu próprio saber. Ele é coletivo, porque são manifestações não individualizadas, como, por exemplo, o folclore ou contos populares. E, finalmente, ele é quantitativo, pois sua produção é feita em grandes números. ${ }^{9}$

Decorrente desse tipo de análise é a compreensão de uma separação entre produção e recepção, criação e consumo. O consumidor de uma obra de arte, de um texto, de uma imagem, estaria inerte diante dos aparelhos impositivos e prontos para aceitar essa produção. As pesquisas de Michel de Certeau colocam em questão essa antiga visão sobre a distância que existe entre criação e consumo:

A uma produção racionalizada, expansionista e centralizada, ruidosa e espetacular, corresponde outra produção, qualificada de 'consumo': esta é astuciosa, ela é dispersa, mas se insinua por todos os lados, silenciosa e quase invisível, pois não se marca por produtos próprios, mas em modo de usar os produtos impostos por uma ordem econômica dominante. ${ }^{10}$

São maneiras de fazer cotidianas que "constituem as mil práticas pelas quais os consumidores se reapropriam do espaço organizado pelas técnicas da produção sociocultural" (Certeau, 1990, p.XL). Logo, não há passividade no consumo de textos. Há uma produção:

considerar a leitura como um acto concreto requer que qualquer processo de construção de sentido, logo de interpretação, seja encarado como estando situado no cruzamento entre, por um lado, leitores dotados de competências específicas, identificados pelas suas posições e disposições, caracterizados pela sua prática do ler, e, por outro, textos cujo significado se encontra sempre dependente dos 
dispositivos discursivos e formais - chamemos-lhes 'tipográficos' no caso dos textos impressos - que são seus. (Chartier, 1990, p.25-26)

A produção do leitor é diferente daquela apropriação material tradicionalmente estudada na História Social, como, por exemplo, os movimentos pelo preço do pão em finais do século XVIII e início do século XIX apresentados por E. P. Thompson, dos quais a resultante seria a formação de uma consciência de classe. Não há um 'lugar' para acumular a apropriação do leitor ou, como diz Michel de Certeau, são táticas do consumidor que agem no tempo, e essa apropriação:

não dispõe de base onde capitalizar os seus ganhos, preparar a sua expansão e adquirir uma independência em relação às circunstâncias ... devido ao seu nãolugar, a tática depende do tempo, permanecendo vigilante para agarrar rapidamente as possibilidades de ganho. O que ela ganha, não guarda. É-lhe necessário jogar constantemente com os acontecimentos para torná-los 'ocasiões'. $\mathrm{O}$ fraco deve tirar partido sem cessar das forças que lhe são estranhas. (Certeau, 1990, p.XLVI)

O leitor não é passivo diante de um maquinário que lhe impõe o que ler e como ler. A despeito das imposições, ele toma o texto para si e o faz funcionar de outro modo, criando formas diferentes de leitura e de compreensão em conformidade com a sua posição social, experiências de vida, educação. Enfim, a sua história lê histórias. Porém, as publicações buscam alcançar essa 'disfunção' que ocorre no tempo a partir do lugar, ou seja, se aproximar dessas práticas cotidianas, levando para o leitor aquilo que ele próprio deseja. Há, portanto, um jogo de aproximações e fugas. O maquinário busca colonizar o leitor que sempre se mostra fugidio e pouco afeito a aceitar passivamente o que lhe é oferecido. É neste aspecto que se busca compreender o leitor e suas práticas, pois:

no ponto de articulação entre o mundo do texto e o mundo do sujeito coloca-se necessariamente uma teoria da leitura capaz de compreender a apropriação dos discursos, isto é, a maneira como estes afectam o leitor e o conduzem a uma nova norma de compreensão de si próprio e do mundo. (Chartier, 1990, p.24)

Para completar, podemos refletir, com Pierre Bourdieu, sobre as práticas dos leitores e sobre como está estabelecida a compreensão da prática social da leitura: 
Historicizar nossa relação com a leitura é uma forma de nos desembaraçarmos daquilo que a história pode nos impor como pressuposto inconsciente. Ao contrário do que se pensa comumente, longe de relativizar ao historizá-la, também nos damos um meio de relativizar sua própria prática, portanto, de escaparmos à relatividade. Se é verdade que o que eu digo da leitura é um produto das circunstâncias nas quais tenho sido produzido enquanto leitor, o fato de tomar consciência disso é talvez a única chance de escapar ao efeito dessas circunstâncias. O que dá uma função epistemológica a toda reflexão sobre a leitura. ${ }^{11}$

A partir dessas observações, podemos entender que os leitores de fotonovelas buscam refazer a narrativa, ou melhor, recriar a narrativa. Esse tipo de arte seqüencial, usando a expressão cunhada por Will Eisner para os quadrinhos, exige do leitor o preenchimento das elipses entre um fotograma e outro: "não é de surpreender que o limite da visão periférica do olho humano esteja intimamente relacionado ao quadrinho usado pelo artista para capturar ou 'congelar' um segmento daquilo que é, na realidade, um fluxo ininterrupto de ação". ${ }^{12} \mathrm{O}$ quadrinho ou a fotonovela demanda um movimento tríplice. $\mathrm{O}$ primeiro movimento seria simples: de um fotograma ao seguinte. Porém, no segundo movimento, entre um fotograma e outro há a elipse que será virtualmente preenchida. E, o terceiro movimento, a reconstituição da narrativa entre os fotogramas com a elipse solucionada imaginariamente. A história é recomposta na mente do leitor. Enfim, há um espaço lacunar nos fotogramas que é preenchido pelo leitor. As poses das personagens e o mise-en-scène deixam um espaço livre para a reconstituição de sentido por parte de quem lê, pois se pode imaginar tanto a seqüência anterior como a posterior até o próximo fotograma (Sullerot, 1963, p.101).

Assim, podemos compreender com Edgar Morin que a fotonovela, como artefato da cultura de massas, exige também, como em todas as manifestações culturais, a participação estética, isto é, um tipo de relação, e

existe, na relação estética, uma participação ao mesmo tempo intensa e desligada, uma dupla consciência. O leitor de romance ou o espectador de filme entra num universo imaginário que, de fato, passa a ter vida para ele, mas ao mesmo tempo, por maior que seja a participação, ele sabe que lê um romance, que vê um filme. ${ }^{13}$

A fotonovela permite a reinvenção da narrativa e coloca o leitor como produtor e não como simples receptor. Cabe, no entanto, reparar que para facilitar o reconhecimento e modificar narrativas, a estrutura da trama deve 
ser simplificada, ampliando as possibilidades de leitura. Nesse aspecto, podemos dizer que a fotonovela retoma a tradição dos folhetins e romances populares do século XIX:

diversamente da tendência burguesa (que vai em direção do psicologismo, os conflitos de sentimentos e de caracteres, dramas ou comédias triangulares do esposo, do amante e da mulher adúltera) a corrente popular permanece fiel aos temas melodramáticos (mistério do nascimento, substituição de crianças, padrastos e madrastas, identidades falsas, disfarces, sósias, gêmeos, rechaços extraordinários, falsas mortes, perseguição da inocência) herdeiros da mais antiga e universal tradição do imaginário (a tragédia grega, o drama elisabetano), mas adaptado ao quadro urbano moderno. No começo do século XX, a diferenciação entre as duas correntes (literatura burguesa e literatura popular) se precisa, tanto mais que durante os trinta primeiros anos do século a corrente popular é que será integrada no cinema e no folhetim barato. (Morin, 1967, p.64)

Além do folhetim, a fotonovela também é filha do cinema. Não é à toa que muitos artistas de cinema e de televisão são chamados para as estrelarem. Deve-se ressaltar que, tanto o folhetim no século XIX quanto o cinema no século XX, não criam do nada as suas histórias. Elas têm um fundo que hoje chamaríamos popular. Se alguns romancistas sofisticaram as suas obras a ponto de torná-las inacessíveis às pessoas comuns, isso não quer dizer que a cultura estava cindida em duas desde o princípio, mas apenas aponta a apropriação exercida pelas classes superiores do campo cultural, marcando a sua distinção social, como vimos.

O encontro entre folhetim e cinema na fotonovela segue uma tradição da literatura oral popular. É o caso do lugar. Nos contos populares quase sempre não há uma definição espacial. Não sabemos onde é a floresta da Chapeuzinho Vermelho, de João e Maria, em qual reino se aventura o Gato de Botas, e não se sabe qual reino é governado pela rainha má da Branca de Neve. O não-lugar dá uma dimensão de universalidade, típico dos contos. Também nas fotonovelas dificilmente aparece algo que possa marcar onde ocorre a trama, a não ser que seja indicado pelo 'narrador', e normalmente são lugares exóticos ou idílicos, conforme certa ideologia popular (Veneza, Paris, Istambul, selvas, desertos, pequenas cidades praianas ou interioranas etc.). Eventualmente, podem-se mostrar nos fotogramas sinais sobre o local real em que se passa a trama, como placas de automóveis ou letreiros de lojas, mas não é possível precisar a locação. Por isso mesmo as histórias podem ser mais didá- 
ticas, passando ao leitor ensinamentos e mensagens rápidas e de fácil compreensão.

Podemos ir um pouco além. Há um fundo hagiográfico na fotonovela. Pode-se perceber, vendo o relato da vida dos santos. A bondade é retribuída com a maldade e o sofrimento só acabará com a recompensa final e absoluta, isto é, a assunção ao paraíso. Já numa sociedade laicizada o amor puro e para o resto da vida coroa o fim do sofrimento e das purgações. Por isso, o herói ou a heroína demonstra logo de início que possui todas as virtudes beatíficas, mas num sentido laico. O caráter dos heróis está predefinido como nos contos hagiográficos, afinal, santidade não conhece variação - ou se é ou não se é santo. Assim, como na hagiografia, sabe-se de antemão qual será o papel do herói, como também do vilão. Também são conhecidos o caráter e a qualidade de cada personagem.

Logo, não se deve buscar na fotonovela a simples identificação da leitora com a trama como forma de escapismo. Como nos contos populares, desejam-se histórias que fujam ao cotidiano e que funcionem como os exempla das hagiografias: o mocinho pobre que se apaixona pela herdeira rica; a operária que desposa o patrão; a heroína que é acusada injustamente de ser ladra e recupera sua honra. Histórias incomuns, até mesmo improváveis, fazem parte da cultura popular.

Mas, além dessa relação com o fora do comum, a fotonovela tem estrutura próxima da hagiografia. Ela denota que, de uma forma laica, as tramas devem trazer explicitamente a ordem do mundo: o certo e o errado, o bem e o mal, o que está acima e o que está abaixo. Nessas histórias, o mal deve ser punido e o bem recompensado. Não há lugar para tentar ultrapassar a ordem do mundo.

A hagiografia fornece exemplum. A vida dos santos mostra o caminho para os fiéis, pois, no fim das contas, são todos imitadores de Cristo. Assim, o sofrimento é suportado com a certeza da felicidade futura. O mal será vencido e o bem triunfará para todo o sempre. O santo, na tradição cristã, não é um ser de vontade, isto é, ele é quase que invariavelmente tocado por forças do bem. Como exemplo, temos Paulo de Tarso. A sua conversão é fruto da aparição do próprio Cristo. Ou ainda Santa Pelágia que, após uma vida de concupiscência e devassidão, é convertida por um padre muito devoto. ${ }^{14}$ Além do toque divino, os santos também podem ser tentados por demônios. Os verdadeiros vencem porque afinal são santos; os que não o são, sucumbem. Foram escolhidos para uma missão, e as hagiografias medievais dificilmente apresentam seres que tenham dúvidas quanto à salvação ou à perdição. 
De maneira análoga, vamos encontrar heróis e heroínas da fotonovela quase nas mesmas condições. Não há profundidade psicológica nas personagens. Desde o primeiro diálogo, o primeiro fotograma em que aparecem, já se conhece o caráter do herói, da heroína. O bem e o mal estão determinados de antemão e não há dúvidas a respeito disso. Normalmente a heroína é casta e segue princípios rígidos como honestidade, lealdade, fidelidade, bondade e desprendimento. $\mathrm{O}$ mesmo é válido para os heróis, que também deverão possuir a qualidade de serem viris, mas não brutos. As virtudes seriam uma forma de enobrecimento das personagens, distinguindo-os tanto dos vilões como das pessoas comuns. Para os vilões, vale o oposto. Agem nas sombras, dissimulam, são avarentos e cúpidos. Não vêem nada além dos seus interesses pessoais, a despeito de todos à sua volta. Muitas vezes, fazem os heróis sofrerem por prazer. Nesse sentido, se aproximam dos demônios das hagiografias. Também neles está expresso, logo à primeira vista, o seu caráter.

A recompensa pelos males sofridos é a felicidade, mas de forma laica. $\mathrm{O}$ paraíso é o amor conquistado e válido para toda a vida. Todo o sofrimento será apagado, e os males serão vencidos ao final da história que, por sua vez, nos remete para um tempo a-histórico: os acontecimentos que desencadearam a trama terminam com o final feliz. Nas narrativas não há um 'antes' e um 'depois'. O antes pode ser comparado a um momento sem história, isto é, sem sucessão temporal. Algo desarranja esse tempo, dando início aos acontecimentos. No final, os eventos são suprimidos por uma "não temporalidade", a felicidade do amor conquistado para o resto da vida. Como em toda parúsia, o fim da trama significa também o fim da própria História. Daí não ser necessária a seqüência da narrativa, pois os heróis entraram no reino da eternidade, representado por amor puro e felicidade plena. A redenção nos contos hagiográficos e nas fotonovelas é para todo o sempre.

Podemos dizer de forma correlata à hagiografia, que a fotonovela "é uma poética do sentido ... o discurso cria uma liberdade com relação ao tempo cotidiano, coletivo ou individual, mas constitui um não-lugar" ${ }^{15}$ Por isso são histórias que se repetem, não por falta de criatividade de muitos roteiristas, mas por serem obrigadas pelo público leitor a fornecer as balizas do mundo. Elas nos dão estabilidade num mundo em mudança. A repetição é por conta dessa configuração temporal e espacial, traduzindo o desejo do retorno dos bons tempos que se realizam poeticamente nas histórias. Por analogia, podemos entender que:

o texto corta o rigor do tempo com o imaginário; reintroduz o respectivo e o cíclico na linearidade do trabalho. Mostrando como ... cria um lugar onde o mesmo 
e olazer se encontram. Este lugar excepcional abre, para cada leitor, a possibilidade de um sentido que é ao mesmo tempo o alhures e o imutável. (Certeau, 1982, p.270)

Podemos utilizar um exemplo, e a escolha é totalmente aleatória. Na revista Grande Hotel ${ }^{16}$ de setembro de 1963, no 835 , é publicada a história "Contigo para sempre". Pelo sobrenome dos atores, percebe-se que são de origem italiana, porém a ação se passa na cidade de Arles, no sul da França. Podemos inferir qualquer coisa porque a cidade foi habitada por Van Gogh, portanto já imortalizada em quadros, e também por se situar na bucólica região da Provence. Mas, no desenrolar da história, percebe-se que por ser uma pequena cidade do interior, ela acaba fazendo o contraponto a Paris, a grande capital.

Relativamente, a trama é bem simples. A ação começa com uma conversa de duas enfermeiras sobre o retorno ao hospital em que trabalham de um renomado cirurgião, Luís, após cinco anos de afastamento em Paris, motivado pela morte de uma paciente na mesa de operação. Quem estava conduzindo os procedimentos, obviamente, era ele próprio. $\mathrm{O}$ destino quis que a paciente fosse a amada do cirurgião, que praticamente morreu em seus braços. Fica-se sabendo que a enfermeira mais jovem, Sara, era próxima da paciente falecida e que não perdoa aquele que seria para ela o responsável pelo seu triste fim. $\mathrm{O}$ trágico está traçado num passado já remoto, mas estende as suas sombras sobre o presente, portanto, é necessário resgatá-lo de algum modo. (Este acontecimento, a morte da amada, dá partida a uma sucessão temporal.)

À chegada de Luís, Sara experimenta sensações fortes, pois o médico, já nomeado diretor do hospital, pede para vê-la, e ela não quer deixar transparecer o rancor que sente. No entanto, tudo muda. Vejamos o que diz o narrador: "O grave rosto de Luís, seus olhos velados de tristeza impressionam Sara. É então aquele o homem que tanto odiou? Uma estranha comoção apoderase dela”. Evidentemente se apaixonam alguns fotogramas adiante, mas não sem obstáculos. O primeiro é superado pelo amor, quando nos é revelado que a pessoa próxima de Sara era na realidade sua irmã, e tinha uma doença incurável, portanto, nada podia salvá-la. Esta é uma boa solução, pois a mocinha não trai a memória da irmã, que iria morrer de qualquer jeito, enquanto o herói purgou durante cinco anos a morte da amada. Dessa maneira, o encontro entre o famoso médico e a simples enfermeira já é o início desse resgate do passado e da superação da perda de ambos.

Porém, mais obstáculos. Forças se levantam contra os heróis. A primeira 
é encarnada num médico, Pedro. Ele é o 'semi-vilão', o que é muito comum nas fotonovelas, alguém que faz algumas maldades mas não é inteiramente mau. Ele é ambicioso e deseja Sara. Sente ciúmes e detesta Luís. Vê uma chance de levar seus intentos adiante quando uma antiga namorada do médico, Irene, vem de Paris à sua procura. Esta é a segunda e mais poderosa força que se abate sobre o casal-herói. Irene tinha aparecido obliquamente através de cartas que enviara a Luís, dizendo que iria atrás dele de qualquer maneira, pois “o amava”. O modo como escreve já nos dá uma dimensão da personagem que se confirma no primeiro fotograma em que aparece. A vilã é extremamente maquiada e veste roupas pouco adequadas para uma mulher de "boa conduta”. Vestidos chamativos, pelo menos é a intenção, caros e algo provocantes. Ela é citadina, e seu corte de cabelo demonstra sofisticação. O coroamento do perfil traiçoeiro da vilã é o carro conversível. Enfim, uma Salomé. Sinais exteriores que traduzem a intencionalidade e também o caráter. Bem ao contrário de Sara, que durante toda a trama aparece de modo recatado, com roupas sóbrias, sem muita maquiagem e com um corte de cabelo simples, de acordo com o que se espera de uma enfermeira dedicada e amorosa.

Luís rechaça Irene. Conhecera-a, em Paris, após a morte de sua amada. Ela queria diversão e ele buscava algum consolo, mas logo percebeu o seu caráter e terminou o relacionamento. No entanto, ela o persegue. Não aceita a recusa de nenhum homem em tê-la em seus braços, e tentará se interpor entre Luís e Sara com ajuda de Pedro. Este logo se arrepende, pede desculpas a Sara e ainda é nomeado primeiro-assistente do hospital, uma forma de redenção e prêmio pela honestidade. Enfim, Luís rechaça definitivamente Irene, e Sara acaba assistindo à cena. Após breve desencontro, no fotograma final ela diz: "Oh, Luís, vou já ao teu encontro, querido... e eu te darei a minha vida, a minha juventude! Estarei contigo para sempre... meu amor!”.

A frase final nos dá a dimensão da suspensão temporal que sofrem as fotonovelas. Do imobilismo inicial ao fim dos acontecimentos, os heróis passam por uma série de purgações, comprovando claramente o seu caráter e denunciando os males que os cercam. Superado o mal, resta o tempo da parúsia, que é o amor terreno para toda a vida, a promessa de felicidade no amor para sempre.

Não há necessidade de nenhuma discussão acerca das decisões das personagens. Elas são tomadas de acordo com seu caráter. Muitas tramas se desenrolam a partir de um quarteto. O herói, a heroína, a vilã e o 'semi-vilão', ou vilão e 'semi-vilã'. As outras personagens dão suporte para o quarteto principal e suas características têm pouca importância para a trama. Não há 
dúvidas. Os principais não desejam riqueza ou poder, mas viver de modo simples, ou seja, bom emprego, boa casa e boa família. Claramente são empregos que poderíamos chamar de pequeno-burgueses. Médicos, jornalistas, pequenos empresários. Mas, mesmo ricos, não compartilham com seus pares da vida de luxo que a riqueza poderia proporcionar. Têm ambições comedidas ou frugais, poderíamos dizer. Normalmente a heroína tem uma profissão próxima da classe operária, ou chega a ser uma operária, mas, às vezes, é de origem pequeno-burguesa e desceu na condição social. De qualquer maneira, os heróis são 'enobrecidos' pelas virtudes inatas que demonstram ao longo da trama quando colocados à prova, distinguindo-se claramente das pessoas comuns e estabelecendo o contraponto extremo aos vilões.

Por isso a fotonovela pode ser um substituto silencioso de relações sociais estáveis e ordenadas. A rápida urbanização no Brasil da década de 1960 e o grande deslocamento de populações criam um mundo instável, no qual muitas relações são efêmeras e outras perigosas - o medo do andarilho, do estranho, do desconhecido. Por isso, histórias que se repetem podem fornecer conforto no meio de tantas mudanças. Sabe-se que há um culto nostálgico do passado. O mito da Idade do Ouro ainda é presente nas sociedades contemporâneas, e

o mundo da Idade do Ouro é o dos relógios parados ... a história em movimento, constante geradora de modernidades sucessivas, fazedora e desfazedora de impérios, de sociedades, de modas e de deuses, vê-se, em compensação, ou violentamente recusada ou deliberadamente ignorada. ${ }^{17}$

O final feliz recompõe o passado e extingue a sucessão temporal. O mundo das fotonovelas é um retorno superior ao passado imóvel.

A ordem nas narrativas, personagens tipologicamente estabelecidas, situações recorrentes e desfechos quase que invariáveis, são balizas para as mudanças que ocorrem diante dos olhos de leitores ávidos por ordem social. As histórias claramente marcadas remetem quem lê para algum tipo de passado, um in illo tempore, isto é, a possibilidade de anular parcialmente o tempo histórico das mudanças, para recompor a realidade de acordo com um passado melhor que o presente. Assim, o pensamento historicista, que deseja ver no homem contemporâneo um ser essencialmente histórico, encontra resistência:

esta posição, ainda que seja a mais moderna e, de certo modo, inevitável para todos os pensadores que definem o homem como um 'ser histórico', não 
conquistou definitivamente o pensamento contemporâneo. Referimos já várias correntes recentes que tendem a revalorizar o mito da periodicidade cíclica e até do eterno retorno (Nietzsche). Essas correntes desprezam não só o historicismo como até a própria história. Pensamos que podemos detectar nelas, mais do que uma resistência à história, uma revolta contra o tempo histórico, uma tentativa de reintegrar esse tempo histórico, carregado de experiência humana, no tempo cósmico, cíclico e infinito. ${ }^{18}$

A noção de uma sociedade estabilizada está associada à idéia de um tempo que não passa ou, se passa, faz-se lentamente.

Percebemos que para essa instabilidade gera-se uma resposta de estabilização. Os mitos contemporâneos, como vimos, são modos de exorcizar o presente da sua inconstância, do tempo histórico ou do terror da história, como afirma Mircea Eliade. A religião reencontrada, o líder, o salvador, a demonização do outro, enfim, várias práticas sociais que, de certa maneira, recompõem mitos antigos em contextos contemporâneos. Podemos entender que "a expressão política da mitologia na Idade de Ouro acaba por ir ao encontro aqui ... desse tema imenso, multiforme, sempre renascente, inscrito sem dúvida no mais profundo da história religiosa da humanidade, que é o do Grande Retorno" (Girardet, 1987, p.137).

O que é mais interessante não é uma possível apropriação do universo popular por um veículo de cultura de massas, mas a permanência desse universo em sociedades de alto capitalismo ou, no mínimo, altamente urbanizadas. Isto é, o público leitor da fotonovela é um público citadino que, no entanto, ainda se deleita com histórias de fundo hagiográfico, porém completamente laicas, atualizando mitos e formas antigas de ordenação da realidade. Pode-se perceber tal estrutura se compararmos as personagens das histórias fotografadas com as vidas dos Santos, como vimos. Os heróis seguem a mesma ordem psicológica das hagiografias. A única coisa que os fará vacilar e ter dúvidas sobre as suas ações é o amor. No entanto, como sentimento superior e objeto final de todas as histórias, ele será o fator decisivo para a resolução da trama, quando o desentendimento, a falsa acusação, a tentação serão superados. Afinal, o amor proibido deixará de sê-lo quando os qüiproquós forem solucionados pela própria força do amor. A morte, prisão ou loucura do oponente malvado liberta o herói de suas dúvidas e o insere no paraíso secular do final feliz.

Por fim, a fotonovela não é uma imposição simples e pura de uma indústria cultural, mas um artefato, no qual leitores podem criar as suas próprias significações e estabelecer suas representações sociais. Porém, há uma grande 
dúvida que percorre os textos dos historiadores que se ocupam dos atos de ler. Podemos reconstruir todas as possíveis significações do texto através das práticas de leitura? Ou o contrário, estas práticas são uma singularidade absoluta? Então, estaríamos numa encruzilhada se, de um lado, insistíssemos em tentativas de empreender totalizações, estabelecendo um objeto fora do que os próprios praticantes fazem ou, de outro, se quiséssemos individualizar ao extremo para termos alguma coisa fiel ao leitor, mas impossível de encontrar correspondências sociais?

A compreensão da leitura não é uma disputa entre atomismo e holismo, ou entre um relativismo absoluto e formas explicativas totalizantes. As práticas são individuais, mas só encontram expressão se forem sociais. Nesse sentido, a 'liberdade' do leitor em relação ao texto é "limitada pelos códigos e convenções que regem as práticas de uma comunidade de pertencimento. Ela é limitada também pelas formas discursivas e materiais dos textos lidos". ${ }^{19}$

A capacidade do leitor de 'inventar' o texto encontra correspondência na capacidade social de estipular o que é ler. Leitura e compreensão do texto são definidas socialmente. A apropriação do lido não deve ser entendida como algo que é estritamente individual, mesmo que seja praticada por indivíduos. Ela é partilhada:

a apropriação, tal como nós a entendemos, visa uma história social dos usos e das interpretações relacionados às suas determinações fundamentais e inscritos nas práticas específicas que os constroem. Dar, assim, atenção às condições de produção do sentido é reconhecer que, contra a antiga história intelectual, nem asidéiasnemasinteligênciassãodesencarnadas...sãopensadasna descontinuidade das trajetórias históricas. (Chartier, 1996, p.214)

Dessa forma, deve-se entender que as mídias modernas não impuseram práticas da leitura e formas de apropriação. A recepção marca a passagem do texto ao leitor. As críticas acerca da produção dos discursos, principalmente as de Michel Foucault, em "Qu'est-ce qu'un auteur" e "L'ordre du discurs", ambos publicados em Dits et écrits, foram incorporadas às práticas dos historiadores. Não há um sujeito puro de enunciação e não há um destinatário puro do discurso. O que existe é uma relação de subjetivação. Assim, o sentido dado pelo leitor ao texto, que hoje é colocado pela História Cultural, especialmente por Roger Chartier, não é a descoberta mais profunda e exata da relação na leitura, mas a mudança na compreensão do indivíduo.

O regime de verdade que Foucault apresenta no século XIX, não deixa de 
mudar ao longo do século XX: de uma exterioridade compartilhada socialmente ela passa a uma subjetividade que só pode ser experimentada e vivenciada em cada pessoa. Daí as dúvidas entre uma narrativa total e um relativismo absoluto. Passou-se, nos últimos anos, de uma história do social à da intimidade; de uma percepção comum da realidade à dos sentimentos individuais que só podem ser compreendidos também individualmente; do Édipo ao Narciso.

A questão não é se render a um ou a outro. Trata-se agora de encontrar as correspondências entre as práticas dos indivíduos no social, para que se possa dar conta do que é comum, isto é, resistir tanto à individualização e ao relativismo absoluto, como à história totalizante. $\mathrm{O}$ estudo das práticas de leitura deve encontrar o indivíduo na sociedade.

Assim, para concluir, a compreensão da fotonovela deve fugir das simplificações que a rejeitam por ser indigna da análise historiográfica. Nela vamos encontrar práticas culturais que podem muito bem nos explicar formas de organização social e modo de agir no cotidiano. Nela se inscrevem práticas que não são resultado de imposições de aparelhos estratégicos dominantes, ao contrário, nela vamos encontrar o desvio e a ordenação do cotidiano de acordo com outra ratio, como afirma Michel de Certeau (1990, p.XLI). Uma ordem que escapa desses aparelhos. Logo:

a tarefa do historiador é, então, reconstruir as variações que diferenciam os 'espaços legíveis' - isto é, os textos nas suas formas discursivas e materiais - e aqueles que governam as circunstâncias de sua efetivação - isto é, as leituras compreendidas como práticas concretas e como procedimentos de interpretação. (Chartier, 1996, p.134)

\section{NOTAS}

${ }^{1}$ BOSI, Alfredo. História concisa da literatura brasileira. 7.ed. São Paulo: Cultrix, 1985. p.197.

${ }^{2}$ Disponível em www.fcsh.unl.pt/edtl/index.htm, 22.01.2008, s.n.p.

${ }^{3}$ ECO, Humberto. Apocalípticos e integrados. 5.ed. São Paulo: Perspectiva, 1993. p.93.

${ }^{4}$ SULLEROT, Evelyne. La presse féminine. Paris: Armand Colin, 1963. p.106. As citações dessa obra receberam tradução livre de minha autoria.

${ }^{5}$ BUITONI, Ducília Helena Schoeder. Fotonovela, infelizmente um quadrado amoroso. 
In: AVERBUCK, Ligia. Literatura em tempo de cultura de massa. São Paulo: Nobel, 1984. p.69.

${ }^{6}$ HABERT, Angeluccia Bernardes. Fotonovela e indústria cultural: estudo de uma forma de literatura sentimental fabricada para milhões. Petrópolis: Vozes, 1984. p.95.

${ }^{7}$ BOURDIEU, Pierre. A economia das trocas simbólicas. Trad. Sérgio Miceli et al. 2.ed. São Paulo: Perspectiva, 1987. p.105.

${ }^{8}$ BURKE, Peter. Cultura popular na Idade Moderna. Trad. Denise Botmann. São Paulo: Companhia das Letras, 1989. p.291.

${ }^{9}$ CHARTIER, Roger. História cultural, entre práticas e representações. Trad. Maria Mauela Galhardo. Lisboa: Difel, 1990. p.54.

${ }^{10}$ CERTEAU, Michel de. L'invention du quotidien. 1. Arts de faire. Paris: Gallimard, 1990. p.XXXVII. As citações dessa obra receberam tradução livre de minha autoria.

${ }^{11}$ BOURDIEU, Pierre; CHARTIER, Roger. A leitura: uma prática cultural. In: BOURDIEU \& CHARTIER. Práticas da leitura. Trad. de Cristiane Nascimento. 2.ed. São Paulo: Estação Liberdade, 2001. p.233-234.

${ }^{12}$ EISNER, Will. Quadrinhos e arte seqüencial. Trad. Luís Carlos Borges. São Paulo: Martins Fontes, 1999. p.38-39.

${ }^{13}$ MORIN, Edgar. A cultura de massas no século XX. Trad. Maura Ribeiro Sardinha. Rio de Janeiro: Forense, 1967. p.81.

${ }^{14}$ VARAZZE, Jacopo de. Legenda Aurea. Trad. Hilário Franco Júnior. São Paulo: Companhia das Letras, 2003. p.849.

${ }^{15}$ CERTEAU, Michel de. A escrita da História. Trad. Maria de Lourdes Menezes. Rio de Janeiro: Forense-Universitária, 1982. p.271.

${ }^{16}$ A revista Grande Hotel, publicação da editora Vecchi, circulou entre as décadas de 1950 e 1970. Chegou a ter uma tiragem quinzenal de mais de 200 mil exemplares nos anos 60 . Após a compra da Vecchi pela Editora Globo, a revista deixou de ser publicada.

${ }^{17}$ GIRARDET, Raoul. Mitos e mitologias políticas. Trad. Maria Lucia Machado. São Paulo: Companhia das Letras, 1987. p.129.

${ }^{18}$ ELIADE, Mircea. O mito do eterno retorno. Trad. Manuela Torres. Lisboa: Edições 70, 1981. p.165.

${ }^{19}$ CHARTIER, Roger. Culture écrite et société. Paris: Albin Michel, 1996. p.137. As citações dessa obra receberam tradução livre de minha autoria.

Artigo recebido em julho de 2008. Aprovado em setembro de 2008. 